\title{
Aplikasi Basis Data Varietas Tanaman Pangan Dan Holtikultura Kalimantan Barat
}

\author{
Rahmat Hidayat Baginda ${ }^{1}$, Heri Priyanto. ${ }^{2}$, Hengky Anra. ${ }^{3}$ \\ Program Studi Teknik Informatika Universitas Tanjungpura ${ }^{l, 2,3}$ \\ ${ }^{1}$ Rahmat.Baginda17@gmail.com, ${ }^{2}$ HeriPriyanto.stmt@gmail.com, ${ }^{3}$ stmt@gmail.com
}

\begin{abstract}
Abstrak - Kondisi lokasi unggulan Tanaman Pangan dan Hortikultura di Kalimantan Barat belum terpetakan sesuai dengan potensi wilayah tiap kabupaten/kota yang ada. Badan yang mengelola saat ini adalah suatu Unit Pengembangan Sertifikasi Benih Tanaman Pangan dan Hortikultura (UPSBTPH) yang berada dibawah naungan Dinas Pertanian Provinsi Kalimantan Barat. Adapun pemetaan yang dilakukan saat ini hanya menggunakan mapinfo dan data statistik dimana sistem pemetaan yang menunjang dalam perancangan sebuah pemetaan persebaran tanaman pangan dan hortikultura kebutuhan informasi secara periodik oleh Pemerintah dan Stake Holder terkait sangat tinggi untuk dapat mengetahui kondisi yang terjadi pada wilayah penghasil tanaman pangan tersebut. Pemanfaatan Metode Cluster Observation yang digunakan dalam Sistem Informasi Pemetaan berguna sebagai metode pemetaan menjadi metode yang dapat membantu dalam mengelompokkan data tersebut.
\end{abstract}

Kata Kunci- Cluster Observation, Geospacial, Tanaman Pangan Hortikultura.

\section{PENDAHULUAN}

Kondisi lokasi unggulan Tanaman Pangan dan Hortikultura di Kalimantan Barat belum terpetakan sesuai dengan potensi wilayah tiap kabupaten/kota yang ada. Badan yang mengelola saat ini adalah suatu Unit Pengembangan Sertifikasi Benih Tanaman Pangan dan Hortikultura (UPSBTPH) yang berada dibawah naungan Dinas Pertanian Provinsi Kalimantan Barat. Adapun pemetaan yang dilakukan saat ini menggunakan mapinfo sebagai perwujudan data statistik yang ada didalam pemetaan. Pemetaan tersebut diharapkan dapat menunjang dalam perencanaan dan perancangan sebuah pemetaan persebaran tanaman pangan dan hortikultura. Sedangkan kebutuhan informasi secara periodik oleh Pemerintah dan Stake Holder terkait sangat tinggi untuk dapat mengetahui kondisi yang terjadi pada wilayah penghasil tanaman pangan tersebut.

Keadaan tersebut menuntut adanya sebuah sistem pemetaan yang dapat memetakan hasil dari analisis sebagai metode pemetaan dari lingkup terkecil sebuah lokus penelitian dan Cluster Observation sebagai metode yang berguna dalam mengklasifikasikan serta mengkategorikan jenis produktifitas unggulan suatu subjek penelitian. Sistem tersebut dapat menghasilkan sampel terkecil dan pengelompokan data yang sama dan dapat diperbarui setiap periode bulan atau tahun dimana sumber data itu berasal, karena kecenderungan saat ini adalah pemerintah melalui UPSBTPH hanya memetakan pada peta statis yang berupa informasi statistik yang ditampilkan pada peta tersebut. Oleh karena itu diperlukan perancangan sistem baru yang diharapkan dapat menunjang dan membantu pemerintah dalam memetakan persebaran tanaman pangan dan hortikultura secara periodik dapat diperbarui oleh admin yang berada di UPSBTPH untuk perancangan laporan kepada pihak pemerintah yang dilakukan setiap bulannya[1].

\section{LANDASAN TEORI}

\subsection{Pemetaan}

Dalam kamus bahasa Indonesia pemetaan atau visualisasi adalah pengungkapan suatu gagasan atau perasaan dengan menggunakan gambar, tulisan, peta, dan grafik. Sementara itu Spasser (1997:78), mengatakan bahwa "peta adalah alat relasi (relational tools) yang menyediakan informasi antarhubungan entitas yang dipetakan.

\subsection{Model Data Spasial}

Model dunia nyata dapat memudahkan manusia dalam studi area aplikasi yang dipilih dengan cara mereduksi sejumlah kompleksitas yang ada. Jika model dunia nyata ini akan digunakan, model ini harus diimplementasikan di dalam basis data. Bentuk representasi entity spasial adalah konsep vektor dan raster. Dengan demikian, data spasial direpresentasikan di dalam basis data sebagai vektor atau raster.

\subsection{Digitasi}

Digitasi merupakan proses pembentukan data yang berasal dari data raster menjadi data vektor. Dalam sistem informasi geografis dan pemetaan digital, data vektor banyak digunakan sebagai dasar analisis dan berbagai proses. Digitasi pada Arcview dilakukan pada 
dokumen view. Dalam pembentukan peta digital, data grafis harus disimpan di dalam sebuah shapefile (file .$s h p$ ). Oleh karena itu, proses digitasi didahului dengan pembuatan sebuah shapefile kosong. Peta hasil digitasi selanjutnya dapat digunakan dalam proses overlay.

\subsection{Overlay}

Overlay merupakan tumpang-susun antara dua peta yang menghasilkan satu unit peta analisis baru. Overlay peta sering dilakukan bersamaan dengan proses skoring. Namun tidak setiap proses tumpangsusun peta selalu menggunakan skoring. Dalam beberapa hal, overlay juga dilakukan antara suatu peta dengan citra satelit atau foto udara. Overlay digunakan sebagai pemadu berbagai indikator yang berasal dari peta tematik hingga menjadi satu peta analisis. Peta analisis ini pada akhirnya digunakan sebagai dasar penarikan kesimpulan untuk suatu kasus.

\subsection{Cluster Observation}

Cluster Observation atau biasa dikenal sebagai analisa gerombol adalah salah satu teknik statistik yang bertujuan untuk mengelompokkan objek kedalam suatu kelompok sehingga objek akan memiliki kesamaan maksimal jika mereka dikelompokkan ke dalam suatu kelompok (Sharma, 2006). Analisa gerombol bertujuan untuk meminimumkan variance antar grup dan memaksimalkan variance di antara grup.

\subsection{Arc Gis 10}

ArcGIS adalah salah satu software yang dikembangkan oleh Environment Science \& Research Institute (ESRI) yang merupakan kompilasi fungsifungsi dari berbagai macam software GIS yang berbeda seperti GIS desktop, server, dan GIS berbasis web. Software ini mulai dirilis oleh ESRI pada tahun 2000. Produk utama dari ArcGIS adalah ArcGIS desktop, dimana arcGIS desktop merupakan perangkat lunak SIG profesional yang komprehensif dan dikelompokkan atas tiga komponen yaitu : ArcView (komponen yang fokus ke penggunaan data yang komprehensif, pemetaan dan analisis), ArcEditor (lebih fokus ke arah editing data spasial) dan ArcInfo (lebih lengkap dalam menyajikan fungsifungsi SI termasuk untuk keperluan analisis geoprosesing).

\subsection{Borland Delphi}

Delphi merupakan paket bahasa pemrograman yang bekerja dalam sistem operasi Windows. Sebagai bahasa pemrograman Delphi memiliki cakupan kemampuan yang luas dan sangat canggih. Berbagai jenis aplikasi dapat dihasilkan dengan Delphi, termasuk aplikasi untuk mengolah teks, grafik, angka, basis data, dan aplikasi web (Alma, 2005). Secara umum, kemampuan Delphi adalah menyediakan komponen-komponen dan bahasa pemrograman yang handal sehingga memungkinkan untuk membuat program aplikasi yang canggih sesuai dengan kebutuhan. Untuk mempermudah dalam pembuatan program aplikasi, Delphi menyediakan fasilitas pemrograman yang sangat lengkap yaitu object dan bahasa pemrograman.

\subsection{My SQL}

MySQL, merupakan aplikasi database server. Perkembangannya disebut SQL yang merupakan kepanjangan dari StructuredQueryLanguage. SQL merupakan bahasa terstruktur yang digunakan untuk mengolah database.

\section{PERANCANGAN SISTEM}

\subsection{Arsitektur Sistem}

Arsitektur sistem menjelaskan komponen-komponen yang terdapat pada sistem. Desain arsitektur sistem dapat dilihat pada Gambar 2 sebagai berikut:

\section{Pengguna}

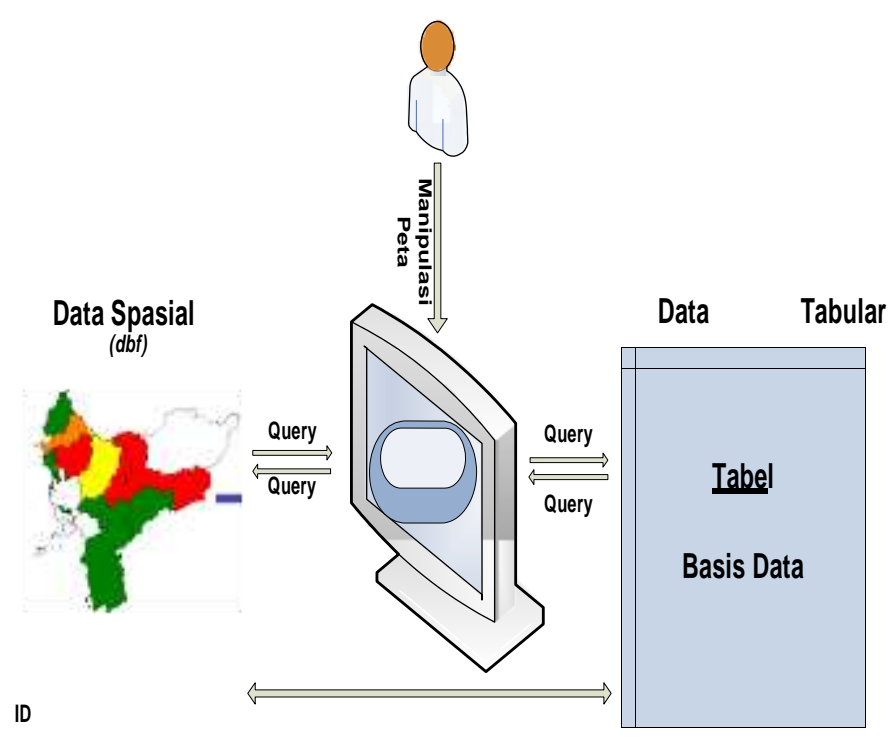

Gambar 2 Arsitektur Sistem

\subsection{Use Case Diagram}

Use Case Diagram berikut memperlihatkan aktoraktor yang terlibar dan daftar kegiatan yang dapat dilakukan dalam sistem yang dirancang. Use case diagram aplikasi dapat dilhat pada gambar 3 . 

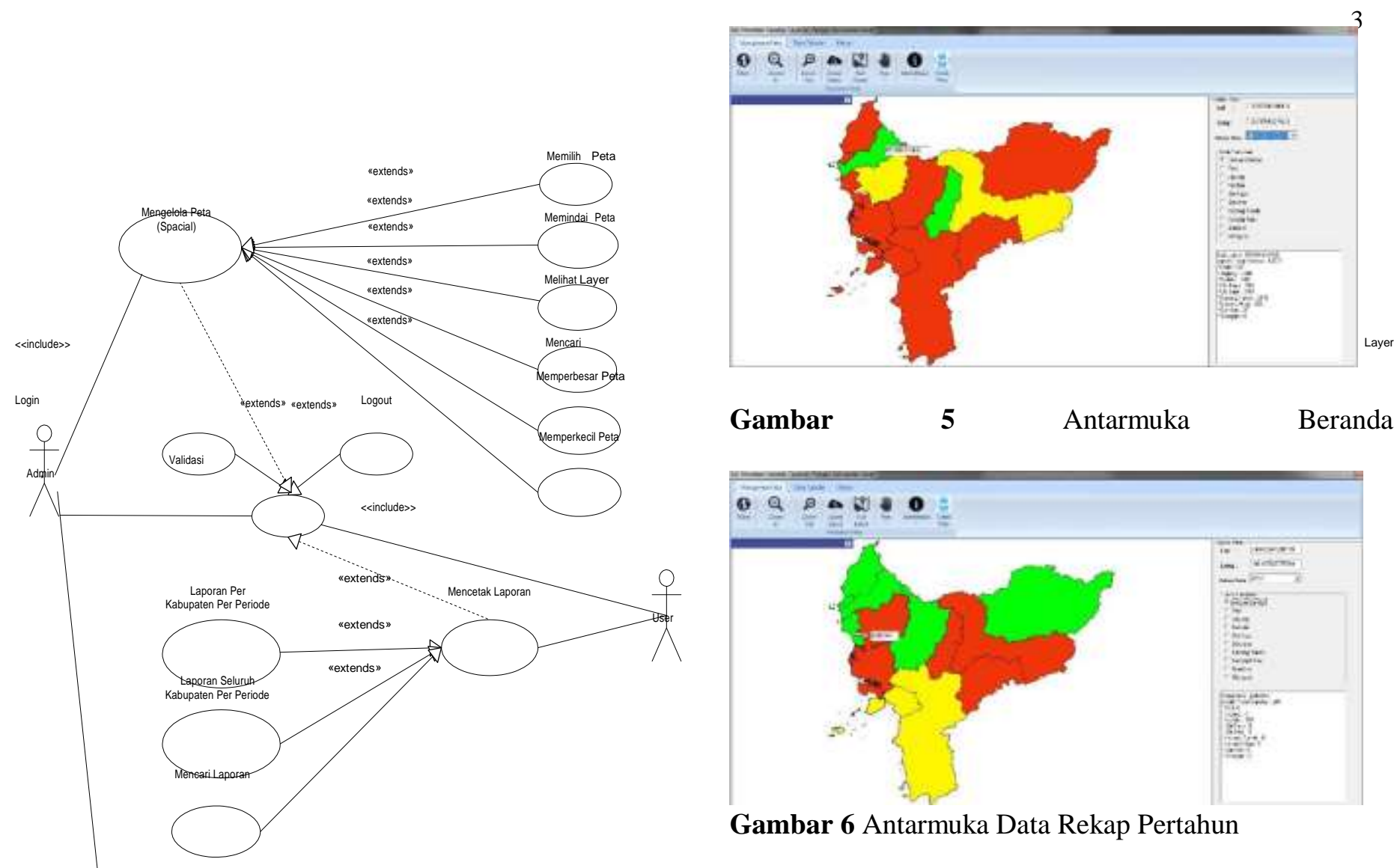

\section{$\begin{array}{llll}\text { Gambar } & 5 & \text { Antarmuka } & \text { Beranda }\end{array}$}

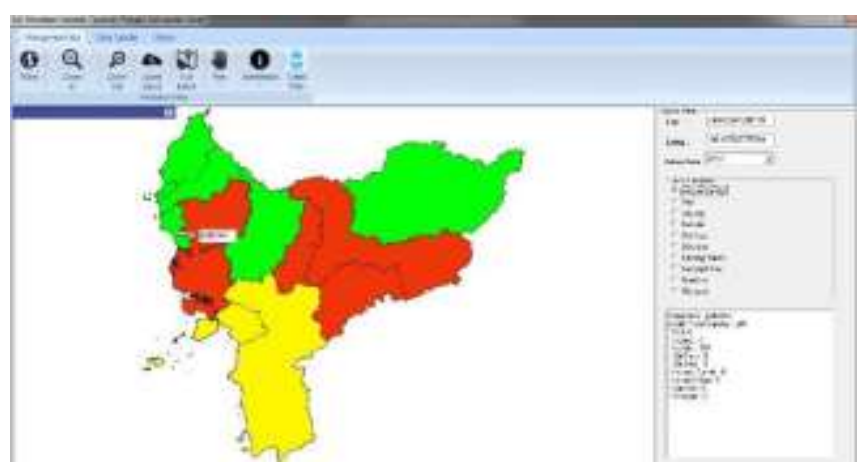

Gambar 6 Antarmuka Data Rekap Pertahun

\subsection{Pengujian BlackBox}

Pengujian blackbox dilakukan untuk mengetahui apakah data telah masuk ke dalam aplikasi. Pengujian

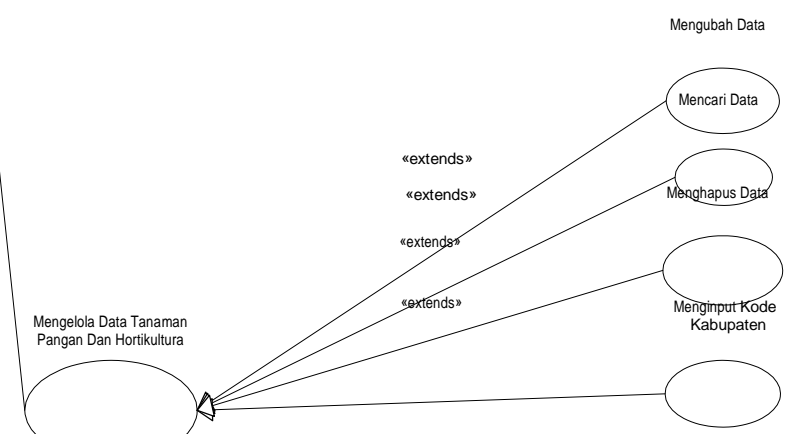

Gambar 3 Use case Diagram blackbox dalam aplikasi dapat lihat pada gambar 7 berikut:

\begin{tabular}{|c|c|c|c|c|}
\hline Input & \multicolumn{2}{|c|}{ Contoh Data } & Hasil & $\begin{array}{l}\text { Keterang } \\
\text { an }\end{array}$ \\
\hline \multirow[b]{2}{*}{$\begin{array}{l}\text { Semua } \\
\text { field } \\
\text { kosong }\end{array}$} & Nama & & \multirow[b]{2}{*}{$\begin{array}{l}\text { Tidak } \\
\text { Berhas } \\
\text { il }\end{array}$} & \multirow{2}{*}{$\begin{array}{l}\text { Muncul } \\
\text { Pesan : } \\
\text { "Data } \\
\text { tidak } \\
\text { boleh } \\
\text { kosong!" }\end{array}$} \\
\hline & $\begin{array}{l}\text { passwor } \\
d\end{array}$ & & & \\
\hline \multirow{2}{*}{$\begin{array}{l}\text { Salah } \\
\text { satu } \\
\text { field } \\
\text { kosong }\end{array}$} & $\begin{array}{l}\text { userna } \\
\text { me }\end{array}$ & user & \multirow[b]{2}{*}{$\begin{array}{l}\text { Tidak } \\
\text { Berhas } \\
\text { il }\end{array}$} & \multirow{2}{*}{$\begin{array}{l}\text { Muncul } \\
\text { Pesan : } \\
\text { "Data } \\
\text { tidak } \\
\text { boleh } \\
\text { kosong!" }\end{array}$} \\
\hline & $\begin{array}{l}\text { passwor } \\
d\end{array}$ & & & \\
\hline \multirow{2}{*}{$\begin{array}{l}\text { Userna } \\
\text { me yang } \\
\text { di } \\
\text { inputkan } \\
\text { tidak } \\
\text { ada }\end{array}$} & $\begin{array}{l}\text { userna } \\
\text { me }\end{array}$ & - & \multirow[b]{2}{*}{$\begin{array}{l}\text { Tidak } \\
\text { Berhas } \\
\text { il }\end{array}$} & \multirow{2}{*}{$\begin{array}{l}\text { Muncur } \\
\text { Pesan : } \\
\text { "Usernam } \\
\text { e dan } \\
\text { password } \\
\text { anda } \\
\text { salah" }\end{array}$} \\
\hline & $\begin{array}{l}\text { passwor } \\
d\end{array}$ & $\begin{array}{l}\text { nam } \\
e\end{array}$ & & \\
\hline
\end{tabular}

$\begin{array}{llll}\text { Gambar } & 7 & \text { Pengujian } & \text { Blackbox. }\end{array}$

Aplikasi yang dirancang merupkan aplikasi basis data varietas tanaman pangan dan hortikultura kalimantan barat. Yang bertujuan memberikan informasi produk unggulan di suatu kabupaten per periode.

\subsection{Hasil Perancangan Aplikasi}

Aplikasi yang dirancang terdiri beberapa form. Adapun form aplikasi adalah sebagai berikut. Antarmuka beranda tampil saat pengguna membuka aplikasi untuk petama kali.

Gambar 


\begin{tabular}{|c|c|c|c|c|}
\hline Input & Contoh & Data & Hasil & $\begin{array}{l}\text { Keterang } \\
\text { an }\end{array}$ \\
\hline $\begin{array}{l}\text { Password } \\
\text { Salah }\end{array}$ & $\begin{array}{l}\text { userna } \\
\text { me } \\
\text { passwo } \\
\text { rd }\end{array}$ & $\begin{array}{l}\text { User } \\
\text { user }\end{array}$ & $\begin{array}{l}\text { Tidak } \\
\text { Berhas } \\
\text { il }\end{array}$ & $\begin{array}{l}\text { Muncul } \\
\text { Pesan : } \\
\text { "Usernam } \\
\text { e dan } \\
\text { password } \\
\text { anda } \\
\text { salah", }\end{array}$ \\
\hline $\begin{array}{l}\text { Username } \\
\text { dan } \\
\text { Password } \\
\text { benar }\end{array}$ & $\begin{array}{l}\text { Userna } \\
\text { me } \\
\text { passwo } \\
\text { rd }\end{array}$ & $\begin{array}{l}\text { User } \\
\text { name }\end{array}$ & $\begin{array}{l}\text { Berhas } \\
\text { il }\end{array}$ & $\begin{array}{l}\text { Muncul } \\
\text { Pesan : } \\
\text { "Anda } \\
\text { telah } \\
\text { login, } \\
\text { selamat } \\
\text { datang" }\end{array}$ \\
\hline
\end{tabular}

Gambar 8 Pengujian Data Input Data Login

Dari gambar 8 terlihat pengujian blackbox di menu pilihan login apabila salah satu data masuk login tidak berhasil dan muncul data tidak boleh kosong, sudah terlihat jelas pada gambar 7,8,9

\subsection{Pengujian Hasil Borang}

Tabel 1 Hasil Borang

\begin{tabular}{|c|c|c|c|c|c|c|c|}
\hline \multirow{2}{*}{ No } & \multirow{2}{*}{ Fungsi } & \multicolumn{5}{|c|}{ Tingkat Kepentingan } & \multirow{2}{*}{ Total } \\
\hline & & $\mathbf{0}$ & 1 & 2 & 3 & 4 & \\
\hline 1 & $\begin{array}{c}\text { Pencarian Data } \\
\text { Produksi pada } \\
\text { Kabupaten } \\
\end{array}$ & 0 & 0 & 3 & 0 & 1 & 4 \\
\hline 2 & $\begin{array}{c}\text { Pencarian Data } \\
\text { Varietas Unggulan } \\
\text { pada Kabupaten } \\
\end{array}$ & 0 & 0 & 2 & 0 & 2 & 4 \\
\hline 3 & Input Data Indikator & 0 & 1 & 1 & 2 & 0 & 4 \\
\hline 4 & $\begin{array}{l}\text { Input Edit Data } \\
\text { Indikator }\end{array}$ & 0 & 0 & 2 & 1 & 1 & 4 \\
\hline 5 & $\begin{array}{l}\text { Input Hapus Data } \\
\text { Indikator }\end{array}$ & 0 & 0 & 0 & 3 & 1 & 4 \\
\hline 6 & $\begin{array}{c}\text { Analisis Penentuan } \\
\text { Produktivitas } \\
\text { Unggulan }\end{array}$ & 0 & 0 & 1 & 2 & 1 & 4 \\
\hline 7 & $\begin{array}{l}\text { Rekap Laporan per } \\
\text { Kabupaten }\end{array}$ & 0 & 0 & 1 & 2 & 1 & 4 \\
\hline 8 & $\begin{array}{c}\text { Cetak Laporan per } \\
\text { Kabupaten }\end{array}$ & 0 & 0 & 0 & 1 & 3 & 4 \\
\hline 9 & $\begin{array}{l}\text { Rekap Laporan per } \\
\text { Periode } \\
\end{array}$ & 0 & 0 & 1 & 1 & 2 & 4 \\
\hline 10 & $\begin{array}{c}\text { Cetak Laporan per } \\
\text { Periode }\end{array}$ & 0 & 0 & 1 & 1 & 2 & 4 \\
\hline 11 & $\begin{array}{c}\text { Grafik Varietas TPH } \\
\text { Unggulan Per } \\
\text { Kabupaten }\end{array}$ & 0 & 1 & 2 & 1 & 1 & 4 \\
\hline & Jumlah & 0 & 1 & 14 & 14 & 15 & 44 \\
\hline & Persentase (\%) & 0 & 2,27 & 31,8 & 31,8 & 34,1 & 100 \\
\hline
\end{tabular}

Keterangan:0 $=$ TidakPerlu 1=Biasa Saja $2=$ Cukup Penting $3=$ Penting $\quad 4=$ Sangat Penting

\begin{tabular}{|l|l|l|l|l|}
\hline \multicolumn{1}{|c|}{ Input } & \multicolumn{2}{|c|}{ Contoh Data } & Hasil & $\begin{array}{l}\text { Keterang } \\
\text { an }\end{array}$ \\
\hline $\begin{array}{l}\text { Semua } \\
\text { field } \\
\text { atau } \\
\text { salah } \\
\text { satu } \\
\text { field } \\
\text { kosong }\end{array}$ & & & Tidak & $\begin{array}{l}\text { Muncul } \\
\text { Pesan : } \\
\text { "Data } \\
\text { belum } \\
\text { lengkap. } \\
\text { Berhahkan } \\
\text { il } \\
\text { diisi!" }\end{array}$ \\
\hline $\begin{array}{l}\text { Input } \\
\text { input- } \\
\text { kan data } \\
\text { dengan } \\
\text { benar }\end{array}$ & Contoh Data & Hasil & $\begin{array}{l}\text { Keteranga } \\
n\end{array}$ \\
\hline
\end{tabular}

Gambar 9 Pengujian Input Data Indikator

Berdasarkan hasil borang pada aspek fungsionalitas tersebut dapat diketahui informasi bahwa sebagian besar responden menanggapi aplikasi sangat penting dengan total tanggapan 4 dengan persentase $34,1 \%$.

Tabel 2 LSR (Likert's Summated Rattings)

\begin{tabular}{|c|c|c|c|c|c|c|c|c|c|c|c|c|}
\hline \multirow{2}{*}{$\begin{array}{c}\text { Respo } \\
\text { nden }\end{array}$} & \multicolumn{7}{|c|}{ Item } & \multirow{2}{*}{ Total } \\
\cline { 2 - 9 } & $\mathbf{1}$ & $\mathbf{2}$ & $\mathbf{3}$ & $\mathbf{4}$ & $\mathbf{5}$ & $\mathbf{6}$ & 7 & 8 & 9 & 10 & 11 & \\
\hline A & 4 & 4 & 3 & 3 & 3 & 3 & 4 & 4 & 4 & 4 & 4 & 40 \\
\hline B & 2 & 4 & 1 & 2 & 3 & 2 & 3 & 4 & 3 & 4 & 2 & 31 \\
\hline C & 2 & 2 & 2 & 2 & 3 & 3 & 2 & 3 & 2 & 2 & 3 & 26 \\
\hline D & 2 & 2 & 3 & 4 & 4 & 4 & 3 & 4 & 4 & 4 & 3 & 35 \\
\hline \multicolumn{7}{|c|}{ Total Skor } & & & 132 \\
\hline
\end{tabular}

Data yang diperoleh dari hasil pengujian dengan borang kemudian diukur dengan metode Likert's Summated Rating (LSR).

a) Jumlah skor untuk setiap responden:

- Skor maksimal = 44 (4 x 11 item)

- Skor minimal $=0(0 \times 11$ item $)$

- Skor median $=22(2 \times 11$ item $)$

- Skor kuartil I = 11 ( 1 x 11 item)

- Skor kuartil III = 33 (3 x 11 item)

b) Jumlah skor untuk seluruh responden:

- Maksimal = $\left.\begin{array}{llll}176 & (4 & \mathrm{x} & 44\end{array}\right)$ 
- Minimal $=0(11 \times 0)$

- Median = 88 (4 x 22)

- Kuartil I = 44 (4 x 11)

- Kuartil III = 132 (4 x 33)

c) Interpretasi jumlah skor tersebut adalah:

- $132<$ Skor <176, artinya sangat positif (program dinilai berhasil)

- $88<$ Skor <132, artinya positif (program dinilai cukup berhasil)

- $44<$ Skor <88, artinya negatif (program dinilai kurang berhasil)

- $0<$ Skor $<44$, artinya sangat negatif (program dinilai tidak berhasil)

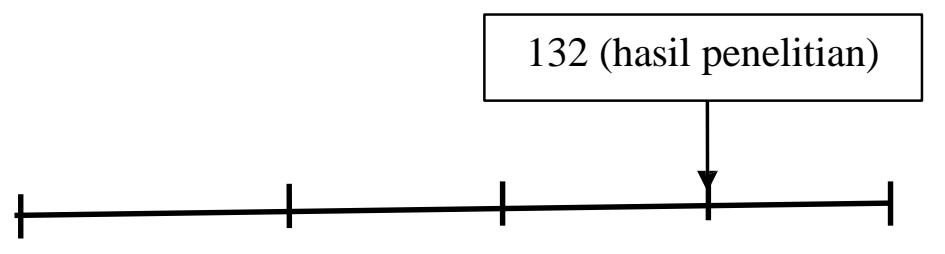

0 44 88

132

176

Gambar 10 Hasil penelitian pada interpretasi LSR.

Gambar tersebut menunjukkan bahwa hasil penelitian berada di antara skor 132-176 yang artinya, hasil borang menandakan responden menilai aplikasi sangat positif dan dinilai berhasil.

a) Berdasarkan hasil analisis data dipetakan 14 kabupaten di provinsi Kalimantan Barat yang unggul dalam jumlah produktivitas terdiri atas Kabupaten Bengkayang dengan jumlah 13302 Ton/tahun, Sekadau berjumlah 9102 Ton/tahun, Landak berjumlah 6471 Ton/tahun, Sintang berjumlah 5873 Ton/tahun, Sanggau berjumlah 2596 Ton/tahun, Kabupaten Pontianak berjumlah 981 Ton/tahun, Sambas berjumlah 807 Ton/tahun, Ketapang berjumlah 784 Ton/tahun, Melawi berjumlah 689 Ton/tahun, Kota Pontianak berjumlah 19 Ton/tahun, Kota Singkawang berjumlah 0 produksi, Kayong Utara berjumlah 0 produksi, Kuburaya berjumlah 0 produksi, Kapuas Hulu berjumlah 0 produksi.

b) Berdasarkan hasil analisis cluster observation, diklasifikasikan 14 kabupaten di provinsi Kalimantan Barat yang dikategorikan produktivitas utama dengan data analisis tahun 2011, yaitu Kabupaten Bengkayang, Sekadau, Landak, Sintang, Sanggau, Kabupaten Pontianak, Sambas, Ketapang, Melawi, Kota Pontianak, Kota Singkawang, Kayong Utara, Kuburaya, Kapuas Hulu. c) Hasil analisis cluster observation juga mengkategorikan empat Kabupaten yang belum dilengkapi dengan data hasil produksi Tanaman Pangan dan Hortikultura diantaranya adalah Kabupaten Kapuas Hulu, Kabupaten Kayong Utara, Kuburaya, Kota Singkawang.

d) Hasil analisis cluster observation pada Jumlah

Produktivitas tiap Kabupaten menunjukkan produktivitas unggulan masing-masing indikator antara lain

\section{KESIMPULAN}

Berdasarkan penelitian yang telah dilakukan mengenai Aplikasi Basis Data Tanaman Pangan dan Hortikultura Kalimantan Barat, maka dapat diambil kesimpulan sebagai berikut:

1. Sistem dapat mengetahui daerah varietas unggulan berdasarkan jumlah produksi unggulan tanaman pangan dan hortikultura yang menghasilkan berupa pemetaan penyebaran tanaman pangan dan hortikultura Kalimantan Barat dengan menggunakan Cluster Observation yang ditujukan kepada UPSBTPH dinas pertanian provinsi Kalimantan

Barat.

2. Sistem dapat membantu pengguna dan pihak UPSBTPH dalam menentukan hasil dari produktivitas unggulan di setiap kawasan yang berupa peta persebaran pada Provinsi Kalimantan Barat berdasarkan parameter Kabupaten / Kota dan Periode Bulan dan Tahun.

3. Berdasarkan hasil analisis cluster observation, berdasarkan akumulasi jumlah tanaman pangan dan hortikulutura secara berurut dari yang paling produktif hingga kurang produktif adalah Bengkayang, Sekadau, Landak. Sintang, Kapuas Hulu, Sambas, Kab Pontianak, Ketapang, Melawi (2011), Kapuas Hulu, Sambas, Bengkayang, Kota Singkawang, Sanggau, Kab. Pontianak, Kayong Utara, Ketapang dan Kota Pontianak (2012), Sambas, Kubu Raya, Sanggau, Kapuas Hulu, Kab Pontianak, Bengkayang, Kota Singkawang, Kayong Utara dan Ketapang (2013)..

\section{SARAN}

Aplikasi yang dirancang tentunya tidak lepas dari kekurangan dan kelemahan. Oleh karena itu, untuk kebaikan pengembangan sistem lebih lanjut, maka perlu diperhatikan beberapa hal, diantaranya:

1. Data spasial dan data tabular yang digunakan untuk pengembangan dari sistem ini diharapkan dapat diperbaharui oleh Dinas UPSBTPH dan BIG, sehingga tidak ada terjadi ketimpangan data setiap periode yang dapat berdampak pada keluaran yang dihasilkan.

2. Data spasial dan data tabular kawasan yang 
digunakan perlu dilengkapi dengan informasi yang lebih mendetail mengenai profil kawasan Kabupaten / Kota yang digunakan misalnya kontur muka bumi dan peta tata guna lahan sebagai bahan perbandingan dalam memberikan informasi dan analisis yang lebih baik.

3. Sistem ini dapat diintegrasikan dengan aplikasi web, sehingga data-data yang ada pada sistem ini berikut hasil analisisnya dapat dilihat oleh masyarakat luas.

\section{DAFTAR PUSTAKA}

[1] A. M. H. Pardede, "SISTEM INFORMASI PEMETAAN PENJUALAN RETAIL DENGAN GOOGLE MAP BERBASIS WEB," BINJAI, 2013.

[2] Alam, M.A.J. 2005. Pemograman Database Borland Delphi dalam SQL Server 7.0 dan 2005. Jakarta: Elex Media Komputindo.

[3] Aziz, T. Lukman. 1996. Sistem Informasi Geografis. Bandung : Institut Teknologi Bandung.

[4] Barus B, Wiradisastra US. 2000. Sistem Informasi Geografis : Sarana Manajemen Sumberdaya. Bogor : Fakultas Pertanian, IPB

[5] Edmond, J.B. 1975 Fundamentals of Historical. TataMcGraw Hill Publ Co. Ltd. New Delhi.

[6] Kadir, Abdul. 2008. Aplikasi Web dengan PHP + Database MySQL. Yogyakarta: Open Source.

[7] Prahasta, Eddy. 2002. Sistem Informasi Geografis Tutorial ArcView. Bandung: Informatika. 